\title{
Pendugaan Evapotranspirasi Padi Sawah dengan Metode Nisbah Bowen
}

\author{
Roberto I. C. O. Taolin ${ }^{\mathrm{a}}$, Impron ${ }^{\mathrm{b}}$, Rini Hidayati ${ }^{\mathrm{b}}$, dan Bregas Budianto ${ }^{\mathrm{b}}$ \\ ${ }^{a}$ Fakultas Pertanian, Universitas Timor, Kefamenanu, TTU - NTT, Indonesia. \\ ${ }^{b}$ Departemen Geofisika dan Meteorologi, Institut Pertanian Bogor, Bogor, Indonesia.
}

\section{Article Info}

Article history:

Received 4 Oktober 2016

Received in revised form 20 Desember 2016

Accepted 9 Februari 2017

\section{Keywords:}

Evapotranspirasi

Nisbah Bowen

Padi Sawah

\section{Abstrak}

Penelitian ini bertujuan untuk menduga nilai evapotranspirasi dengan metode Nisbah Bowen di lahan sawah Kabupaten Indramayu yang sering mengalami permasalahan keterbatasan sumberdaya air terutama pada akhir musim tanam kedua/gadu setiap tahun, dilaksanakan bulan Juni hingga September 2012. Komponen cuaca yang diukur dengan sistem Nisbah Bowen adalah radiasi neto, suhu bola basah dan bola kering, gradien suhu bola basah dan bola kering pada ketinggian antara $140 \mathrm{~cm}$ dan $160 \mathrm{~cm}$ serta pada ketinggian antara $160 \mathrm{~cm}$ dan $180 \mathrm{~cm}$ dan limpahan bahang tanah. Pengukuran setiap 30 menit mulai pukul 06.00 sampai pukul 18.00 Komponen yang diukur dengan AWS adalah radiasi, suhu, kelembaban, tekanan udara, curah hujan, arah dan kecepatan angin. Perhitungan dengan metode Nisbah Bowen kemudian dibandingkan dengan perhitungan menggunakan metode FAO Penman-Monteith. Hubungan evapotranspirasi harian hasil perhitungan dengan dua metode tersebut dianalisis dengan Korelasi (Pearson Correlation). Hasil penelitian menunjukkan evapotranspirasi harian di areal persawahan Kabupaten Indramayu pada saat periode kekeringan musim tanam II yang diduga menggunakan metode Nisbah Bowen berkisar antara antara 2,4 mm sampai 4,3 mm dengan rata-rata $3,3 \mathrm{~mm}$, sedangkan evapotranspirasi harian yang diduga menggunakan metode FAO Penman-Monteith bervariasi antara 2,4 mm sampai 4,6 mm dengan rata-rata 3,5 mm. Rata-rata hasil estimasi evapotranspirasi harian dari kedua metode secara statistik tidak berbeda nyata. (O2017 dipublikasikan oleh Savana Cendana.

\section{Pendahuluan}

Evapotranspirasi merupakan salah satu bagian dalam siklus air, dan memiliki peran yang penting bagi pertanian, hidrologi, ekologi dan bidang lainnya. Wang et al. (2012) mendefinisikan evapotranspirasi sebagai perubahan wujud dari $\mathrm{H}_{2} \mathrm{O}$ cair menjadi uap atau gas serta bergerak dari bidang penguap (permukaan tanah dan vegetasi) ke atmosfir. Perhitungan evapotranspirasi antara lain diperlukan untuk menentukan besarnya penggunaan air konsumtif untuk tanaman, analisis ketersediaan air, kapasitas pompa untuk irigasi, air yang dialirkan melalui saluran irigasi dan kapasitas waduk.

Laju evapotranspirasi dapat diukur secara langsung atau dapat juga diestimasi dengan beberapa pendekatan atau metode seperti pendekatan iklim mikro maupun pendekatan empirik. Pendugaan nilai evapotranspirasi antara lain dapat dilakukan dengan menggunakan metode Nisbah Bowen dan metode $F A O$ Penman-Monteith. Beberapa peneliti di berbagai negara telah membuktikan kehandalan metode Nisbah Bowen, terutama menyangkut proses-proses fisik (pemindahan energi) di atas permukaan tajuk yang sulit dijelaskan melalui metode lain dalam kaitannya dengan evapotranspirasi. Pengukuran dengan metode Nisbah Bowen dapat dilakukan langsung di lapangan (in situ) tanpa gangguan fisik terhadap lahan dan hasil pendugaan dapat menghitung laju evapotranspirasi dalam periode pendek, misalnya per jam atau tiap setengah jam (Grant, 1975).

Laju evapotranspirasi dari suatu pertanaman sangat tergantung pada ketersediaan energi, defisit tekanan uap, kecepatan angin dan suhu udara, sedangkan faktor vegetasi yang berpengaruh adalah hantaran stomata/tajuk dan struktur karakteristik tajuk yang berpengaruh pada hantaran aerodinamik (Jarvis dan Stewart 1979). Evaporasi dari suatu permukaan dapat ditentukan dengan baik jika semua komponen yang mempengaruhi neraca energi di permukaan yang bersangkutan diketahui, yaitu radiasi neto $\left(\mathrm{R}_{\mathrm{n}}\right)$, fluks bahang terasa $(\mathrm{H})$ dan fluks bahang tanah $(\mathrm{G})$. $\mathrm{R}_{\mathrm{n}}$ dan $\mathrm{G}$ yang dapat diukur secara langsung dan mudah. $\mathrm{H}$ dan LE dapat dihitung dengan menggunakan metode Nisbah Bowen (Rosenberg et al. 1983).

Menurut Bowen (1926) perbandingan antara H dan LE dapat dinyatakan sebagai Nisbah Bowen (Bowen Ratio) yang dilambangkan dengan $\beta$, yang juga merupakan fungsi perbedaan pengukuran secara vertikal dari suhu udara dan tekanan uap air aktual pada dua ketinggian yang berbeda. Selanjutnya menuru Angus dan Watts (1984), penggunaan metode ini memerlukan beberapa syarat Pertama adalah koefisien pemindahan turbulen untuk bahang terasa $\left(\mathrm{K}_{\mathrm{h}}\right)$ adalah sama dengan koefisien pemindahan turbulen bahang laten $\left(\mathrm{K}_{\mathrm{w}}\right)$, hal ini dapa terjadi pada saat kondisi kestabilan udara tidak jauh dari keadaan netral dan d atas permukaan yang cukup lembab. Selain itu peralatan pengukur yang diperlukan harus berketelitian tinggi dan ditempatkan di lapisan pembatas internal (internal boundary layer) dimana sifat udara sepenuhnya dipengaruh oleh permukaan. Oleh karena itu diperlukan fetch yang lebar, paling sediki seratus kali ketinggian alat pengukur, untuk menghindarkan gradien suhu dan kelembaban secara horisontal.

Nisbah Bowen dapat diperoleh melalui pengukuran menggunakan sepasang psikrometer dengan tingkat ketelitian yang tinggi. Tanner (1966) menyatakan Sensor suhu bola basah memerlukan media yang dapat memberi selaput tipis ai secara konstan. Bahan yang sering digunakan adalah kain katun, bahan tersebut terpasang rapat pada sensor sehingga selaput tipis air dapat selalu terjaga. Cara pemberian air menggunakan prinsip kapilaritas untuk mencegah menumpuknya air di sekitar sensor.

Dalam penelitian ini, pengukuran selisih suhu yang dilakukan pada dua leve ketinggian yang berbeda menggunakan beberapa termokopel yang terhubung secara seri dengan posisi sensor menjorok ke tiga arah yang berbeda. Penelitian ini bertujuan untuk menduga nilai evapotranspirasi dengan metode Nisbah Bowen di lahan sawah Kabupaten Indramayu yang sering mengalami permasalahan keterbatasan sumberdaya air terutama pada akhir musim tanam kedua/gadu setiap tahun.

\section{Metode}

Penelitian dilaksanakan pada bulan Juni hingga September 2012. Perakitan alat Nisbah Bowen dilakukan di Laboratorium Instrumentasi Meteorologi Departemen Geofisika dan Meteorologi, FMIPA, Institut Pertanian Bogor Percobaan lapang dilaksanakan di persawahan yang terletak di Desa Langgengsari, Kecamatan Lelea, Kabupaten Indramayu, Provinsi Jawa Barat. Bahan yang digunakan dalam penelitian ini adalah pipa PVC ukuran 1 inci (AW 1"), sambungan pipa, perekat pipa PVC, alumunium foil, benang, kawat solder, kawat tembaga, kawat konstantan dan selang pelindung kawat/kabel. Alat yang digunakan dalam penelitian ini adalah Middleton CN1 Net Pyrradiometer S/No.1108, termokopel type T (Copper/Constantan), pengganda tegangan (OpAmp), Automatic Weather Station (AWS), data logger type GL500, digital multimeter type DT-830B, solder listrik, thermometer air raksa, keping sensor fluks panas (Soil Heat Flux Plate), botol berukuran $10 \mathrm{ml}$, kipas penyedot udara dan aki 6 volt model Panasonic LC-R064R5P.

Perakitan alat Nisbah Bowen meliputi pembuatan termokopel tipe T, pembuatan pengganda tegangan (amplifier) dan pembuatan tiang penyangga. Termokopel (sensitifitas $43 \mu \mathrm{V}{ }^{\circ} \mathrm{C}^{-1}$ ) dibuat dengan cara menghubungkan tembaga sebagai konduktor positif dan konstantan sebagai konduktor negatif Jumlah termokopel yang dibuat adalah 12 buah dan setiap tiga buah termokopel dihubungkan secara seri sehingga terdapat 4 paket termokopel yang setiap kawat konduktornya dilindungi dengan selang pelindung kawat/kabel. Pada titik-titik sambungan pada dua paket termokopel diberikan lilitan benang untuk kepentingan pengukuran gradien suhu bola basah. Rangkaian termokopel dapat dilihat pada Gambar 1
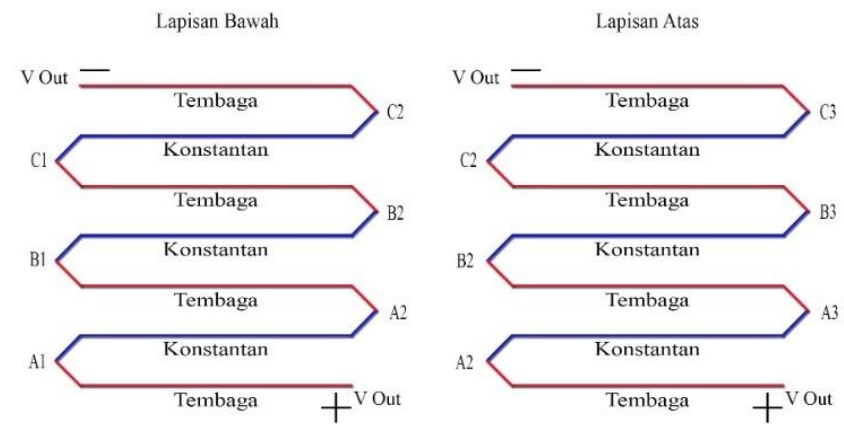

Gambar 1 Rangkaian termokopel (Taolin et al., 2017)

Pengganda tegangan (Op-Amp) merupakan rangkaian elektronik yang berfungsi untuk mengolah arus listrik termokopel yang berupa tegangan yang kecil menjadi tegangan yang lebih besar, sehingga output dari rangkaian ini dapat dibaca oleh multimeter. Pengganda tegangan yang dibuat memberikan penguatan 250 kali sehingga output pengganda tegangan ini memiliki karakteristik yang linear dengan sensitifitas $11 \mathrm{mv}^{\circ} \mathrm{C}^{-1}$.

Tiang penyangga dibuat dengan bahan dasar pipa PVC berukuran 1 inci dengan tinggi $200 \mathrm{~cm}$. Bagian ujung atas disediakan tempat untuk pemasangan net pyrradiometer. Pada ketinggian $140 \mathrm{~cm}, 160 \mathrm{~cm}$ dan $180 \mathrm{~cm}$ disiapkan tempat pemasangan 4 paket psikrometer elektronik yang menjorok secara horizontal sepanjang $40 \mathrm{~cm}$ pada tiga arah yang berbeda membentuk sudut $120^{\circ}$ seperti pada Gambar 2.

Termokopel dipasang melalui bagian dalam pipa dan menempatkan sensor di bagian ujung-ujung pipa yang menjorok $(\mathrm{A} 1-\mathrm{C} 3)$. Ujung benang yang terlili pada termokopel direndam dalam botol penampungan yang berisi air sehingga menghasilkan aliran kapiler untuk pembasahan sensor. Pada ujung bawah penyangga dipasang kipas penyedot udara yang dihubungkan dengan aki. 


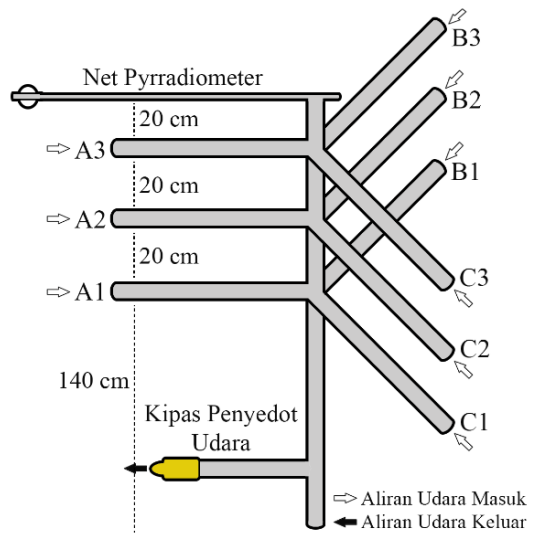

Gambar 2 Rancangan sistim Nisbah Bowen (Taolin et al.., 2017)

Alat yang dipasang di areal percobaan meliputi sistem Nisbah Bowen, sepasang termometer air raksa (bola kering dan bola basah) dan Automatic Weather Station (AWS). Sistem Nisbah Bowen ditempatkan di areal persawahan dengan memperhatikan lebar fetch yakni lebih dari 100 kali ketinggian sensor. Keping sensor limpahan bahang tanah dipasang di bawah sistem Nisbah Bowen dengan kedalaman $20 \mathrm{~cm}$ dari permukaan tanah. Sepasang termometer air raksa ditempatkan pada tiang penyangga berbeda dengan ketinggian $2 \mathrm{~m}$ dari permukaan tanah.

Komponen cuaca yang diukur dengan sistem Nisbah Bowen adalah radiasi neto, suhu bola basah dan bola kering, gradien suhu bola basah dan bola kering pada ketinggian antara $140 \mathrm{~cm}$ dan $160 \mathrm{~cm}$ serta pada ketinggian antara $160 \mathrm{~cm}$ dan $180 \mathrm{~cm}$ dan limpahan bahang tanah. Pengukuran setiap 30 menit mulai pukul 06.00 sampai pukul 18.00 dilakukan dengan cara menghubungkan multimeter pada pengganda tegangan kemudian dilakukan pembacaan nilai offset dan selanjutnya dihubungkan pada masing-masing sensor, sedangkan untuk net pyrradiometer dan keping sensor limpahan bahang dilakukan dengan cara langsung dihubungkan dengan multimeter. Komponen yang diukur dengan AWS adalah radiasi $\left(\mathrm{W} \mathrm{m}^{-2}\right)$, suhu $\left({ }^{\circ} \mathrm{C}\right)$, kelembaban $(\%)$, tekanan udara (mBar), curah hujan $(\mathrm{mm})$, arah angin $\left({ }^{\circ}\right)$ dan kecepatan angin $\left(\mathrm{km} \mathrm{jam}^{-1}\right)$. Pencatatan data dilakukan setiap 30 menit menggunakan data logger type GL500.

Data hasil pengukuran kemudian ditabulasi untuk kepentingan perhitungan evapotranspirasi harian yang terjadi di lokasi penelitian. Perhitungan dengan metode Nisbah Bowen kemudian dibandingkan dengan perhitungan menggunakan metode FAO Penman-Monteith. Hubungan evapotranspirasi harian hasil perhitungan dengan metode Nisbah Bowen dan evapotranspirasi tanaman harian menggunakan metode FAO Penman-Monteith kemudian dianalisis dengan Korelasi (Pearson Correlation) menggunakan program SPSS 17.0.

\section{Hasil dan Pembahasan}

\subsection{Karakteristik Persawahan dan Tanaman Padi Selama Periode} Pengukuran

Sawah lokasi pengukuran merupakan hamparan persawahan petani. Musim tanam II umumnya menggunakan varietas Ciherang, puncak penanaman terjadi pada bulan Mei dan awal Juni. Untuk kepentingan penelitian, dilakukan budidaya padi pada lahan seluas $5.092,5 \mathrm{~m}^{2}$. Varietas padi yang digunakan adalah Ciherang, Inpari 10 dan Inpari 13 yang ditanam pada tanggal 25 Juni 2012.

Dari hasil pengamatan, periode kekeringan mulai berlangsung di lokasi penelitian pada pertengahan bulan Juli, dimana tidak ada lagi suplai air melalui saluran irigasi, sedangkan tanaman padi yang dibudidayakan petani pada umumnya sedang dalam tahap matang susu (Milk Grain Stage) yang membutuhkan ketersediaan air. Untuk mencegah gagal panen, sebagian petani memanfaatkan air tanah dengan membuat sumur bor untuk terus mengairi sawah sehingga pertumbuhan padi dapat dipertahankan semaksimal mungkin. Periode pengukuran dimulai tanggal 8 Agustus saat tanaman padi yang dibudidayakan untuk penelitian telah berumur 42 HST dengan pemberian air dilakukan seminggu sekali dari hasil pemompaan sumur bor. Selama periode pengukuran tidak terjadi hujan.

\section{Tabel 1. Pertumbuhan dan Produksi Tanaman Padi}

\begin{tabular}{lrrr}
\hline \multicolumn{1}{c}{ Parameter } & \multicolumn{3}{c}{ Varietas } \\
\cline { 2 - 4 } & Ciherang & Inpari 10 & Inpari 13 \\
\hline Tinggi Tanaman (cm) & 80,7 & 78,7 & 87,7 \\
Jumlah Anakan Produktif & 9,7 & 9,0 & 9,0 \\
Indeks Luas Daun & 1,6 & 1,6 & 1,3 \\
Berat Kering Tanaman 70 HST $\left(\mathrm{g} \mathrm{m}^{-2}\right)$ & 548,7 & 532,8 & 406,3 \\
\% Gabah Isi & 32,2 & 32,0 & 46,8 \\
Jumlah Gabah/Malai & 67,5 & 80,4 & 94,8 \\
Bobot 1000 Biji (g) & 12,2 & 14,5 & 19,9 \\
Produktivitas (t ha & 1,6 & 1,7 & 2,0 \\
\hline
\end{tabular}

Panen dilakukan lebih awal oleh petani sejak pertengahan Agustus dengan puncak panen terjadi pada dan awal September sedangkan tanaman padi yang dibudidayakan untuk penelitian dipanen pada tanggal 15 September. Secara umum pertumbuhan dan produksi tanaman tidak maksimal akibat kekurangan air.

\subsection{Komponen Cuaca dan Parameter Nisbah Bowen}

Fluktuasi cuaca harian dan parameter Nisbah Bowen umumnya mengikuti penerimaan radiasi neto sesuai karakter masing-masing seperti suhu, gradien suhu bola kering, kecepatan angin, limpahan bahang tanah dan limpahan bahang laten yang meningkat selama siang hari dan menurun kembali menjelang sore hari. Sebaliknya, gradien suhu bola basah, kelembaban dan tekanan udara, menurun selama siang hari dan kembali meningkat menjelang sore hari. Variasi diurnal radiasi neto berkisar antara $-47 \mathrm{~W} \mathrm{~m}^{-2}$ sampai $487 \mathrm{~W} \mathrm{~m}^{-2}$ dengan rata-rata $241 \mathrm{~W} \mathrm{~m}^{-2}$, suhu udara rata-rata $28,3{ }^{\circ} \mathrm{C}$ dengan suhu tertinggi $31,5^{\circ} \mathrm{C}$ dan suhu terendah $20,5{ }^{\circ} \mathrm{C}$. Kelembaban relatif berkisar antara $52 \%$ hingga $80 \%$ dengan rata-rata $66 \%$, sedangkan tekanan udara rata-rata $101 \mathrm{kPa}$. Limpahan bahang tanah berkisar antara antara $-10,3 \mathrm{~W} \mathrm{~m}^{-2}$ sampai $19,3 \mathrm{~W} \mathrm{~m}^{-2}$ dengan rata-rata 8,1 $\mathrm{W} \mathrm{m}^{-2}$ sedangkan Nisbah Bowen berkisar antara $-0,76$ sampai 0,65 dengan ratarata 0,16 . Limpahan bahang laten berkisar antara $-85,3 \mathrm{~W} \mathrm{~m}^{-2}$ sampai $392,3 \mathrm{~W}$ $\mathrm{m}^{-2}$ dengan rata-rata $172,9 \mathrm{~W} \mathrm{~m}^{-2}$.

Rata-rata harian radiasi neto yang diterima permukaan selama penelitian relatif konstan antara $183 \mathrm{~W} \mathrm{~m}^{-2}$ sampai $268 \mathrm{~W} \mathrm{~m}^{-2}$ dengan rata-rata $231 \mathrm{~W} \mathrm{~m}^{-2}$, suhu udara rata-rata $29,4{ }^{\circ} \mathrm{C}$ dengan suhu maksimum $35,5^{\circ} \mathrm{C}$ dan suhu minimum $20{ }^{\circ} \mathrm{C}$. Kelembaban relatif berkisar antara $45 \%$ hingga $67 \%$ dengan rata-rata $59 \%$, sedangkan tekanan udara rata-rata $101 \mathrm{kPa}$. Angin bertiup lebih banyak ke arah tenggara $\left(138,4^{\circ}\right)$ dengan kecepatan rata-rata $0,9 \mathrm{~m} \mathrm{~s}^{-1}$. Limpahan bahang tanah selama penelitian cukup tinggi terutama menjelang akhir penelitian dimana tanah sudah semakin kering. Selama penelitian limpahan bahang tanah berkisar antara $4,7 \mathrm{~W} \mathrm{~m}^{-2}$ sampai $14,6 \mathrm{~W} \mathrm{~m}^{-2}$ dengan rata-rata $7,9 \mathrm{~W} \mathrm{~m}^{-2}$ sedangkan Nisbah Bowen berkisar antara 0,02 sampai 0,22 dengan rata-rata 0.10. Limpahan bahang laten berbanding lurus terhadap penerimaan radiasi neto yang mengenai kawasan persawahan dengan nilai berkisar antara $134,4 \mathrm{~W} \mathrm{~m}^{-2}$ sampai $226,5 \mathrm{~W}$ $\mathrm{m}^{-2}$ dengan rata-rata $184 \mathrm{~W} \mathrm{~m}^{-2}$.

Perbandingan Rn, LE, H dan G pada pukul 06.00 sampai pukul 18.00 dapat dilihat pada Gambar 3. Pada tanggal 8 Agustus 2012, hanya 2,5\% masukan energi yang digunakan sebagai limpahan bahang tanah dan sejumlah $9,9 \%$ yang digunakan untuk pemanasan udara sedangkan sisanya sebesar $87,6 \%$ digunakan sebagai limpahan bahang laten. Pada tanggal 21 Agustus 2012, hanya 2,5\% masukan energi yang digunakan sebagai limpahan bahang tanah dan masukan energi yang digunakan untuk pemanasan udara meningkat menjadi $29,9 \%$ sedangkan sisanya sebesar $67,6 \%$ digunakan sebagai limpahan bahang laten Pada tanggal 7 September 2012, masukan energi yang digunakan sebagai limpahan bahang tanah meningkat menjadi 5\% dan sejumlah 23,9\% yang digunakan untuk pemanasan udara sedangkan sisanya sebesar 71,0\% digunakan sebagai limpahan bahang laten.

Secara umum, selama penelitian rata-rata 97,3\% dari $\mathrm{Rn}$ yang diterima permukaan sawah digunakan untuk menguapkan air ke atmosfir dan LE memilik nilai yang berbanding lurus terhadap penerimaan radiasi neto yang mengenai kawasan persawahan tersebut.

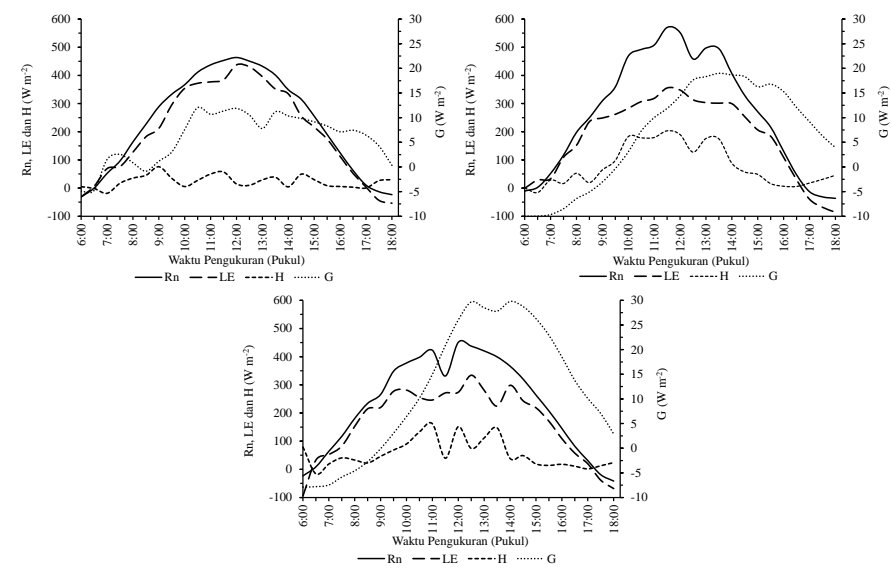

Gambar 3 Variasi diurnal radiasi neto (Rn), limpahan bahang laten (LE) dan limpahan bahang tanah (G) tanggal 8 Agustus 2012 (atas kiri), 21 Agustus 2012 (atas kanan) dan 7 September 2012 (bawah)

\subsection{Evapotranspirasi}

Hasil estimasi evapotranspirasi harian menggunakan metode Nisbah Bowen selama penelitian berkisar antara $2,4 \mathrm{~mm}$ sampai $4,3 \mathrm{~mm}$ dengan rata-rata $3,3+0,4 \mathrm{~mm}$. Hasil ini lebih rendah dari evapotranspirasi harian yang diukur oleh Abdullahi et al. (2013) menggunakan lisimeter pada berbagai tahap pertumbuhan tanaman padi di Kelantan Malaysia pada tahun 2008 yang berkisar antara 2,9 mm sampai $7,3 \mathrm{~mm}$ dengan rata-rata $4,8 \mathrm{~mm}$ dan $5,6 \mathrm{~mm}$ pada dua plot yang berbeda. Kondisi cuaca sangat menentukan laju evapotranspirasi yang terjadi dan sebaliknya evapotranspirasi juga mempengaruhi cuaca. Jumlah terbesar dari energi yang digunakan pada proses evapotranspirasi tersedia dari radiasi surya selain dari perpindahan energi secara horizontal. Fluktuasi harian atau pola limpahan bahang laten dan laju evapotranspirasi memiliki kemiripan atau 
mengikuti fluktuasi radiasi neto, hal ini menggambarkan bahwa radiasi neto memiliki pengaruh yang besar terhadap evapotranspirasi.

Siang hari saat radiasi matahari mencapai puncak yakni pada pukul 12.00 evapotranspirasi dapat mencapai $0,54 \mathrm{~mm} \mathrm{jam}^{-1}$, kemudian menurun hingga mencapai nilai minimum sebesar $0,04 \mathrm{~mm} \mathrm{jam}^{-1}$ pada pukul 16.30 . Ketersediaan energi yang terus meningkat sejak pagi hari sebagian digunakan untuk pemanasan udara dimana peningkatan suhu hingga siang hari menyebabkan kapasitas udara menampung uap air semakin besar sehingga memungkinkan udara lebih banyak menampung uap air sehingga proses evapotranspirasi intensif. Peningkatan defisit tekanan uap di udara menjadi faktor pendukung terjadinya evapotranspirasi karena adanya perbedaan tekanan uap yang makin besar antara permukaan penguapan dan udara sehingga memungkinkan terjadinya pergerakan udara basah secara vertikal.

\subsection{Perbandingan Nilai Evapotraspirasi Menggunakan Metode Nisbah} Bowen dengan Metode FAO Penman-Monteith

Hasil estimasi evapotranspirasi harian menggunakan metode FAO PenmanMonteith selama penelitian bervariasi antara 2,4 $\mathrm{mm}$ sampai 4,6 $\mathrm{mm}$ dengan ratarata 3,5 $\mathrm{mm}$. Hal ini memberikan gambaran bahwa estimasi evapotranspirasi harian dengan metode FAO Penman-Monteith memberikan nilai lebih tinggi dengan selisih $0,2 \mathrm{~mm}$ dibanding estimasi evapotranspirasi harian dengan metode Nisbah Bowen. Perbandingan estimasi evapotranspirasi harian dari kedua metode tersebut dapat dilihat pada Gambar 4.

Selisih perhitungan evapotranspirasi kedua metode dipengaruhi oleh pendekatan yang berbeda pada masing-masing metode. Salah satu perbedaan yang mononjol adalah metode Nisbah Bowen mengukur evapotranspirasi yang terjadi berdasarkan proses-proses fisika yang terjadi pada permukaan lingkungan tanaman dimana hal tersebut dipengaruhi oleh perubahan fisik dari tanaman dari waktu ke waktu secara terus menerus, sedangkan pada metode FAO PenmanMonteith perubahan fisik tanaman diperhitungkan menggunakan koefisien tanaman dimana koefisien tanaman hanya dibedakan pada beberapa fase perkembangan tanaman, setiap fase perkembangan memiliki koefisien tanaman yang sama.

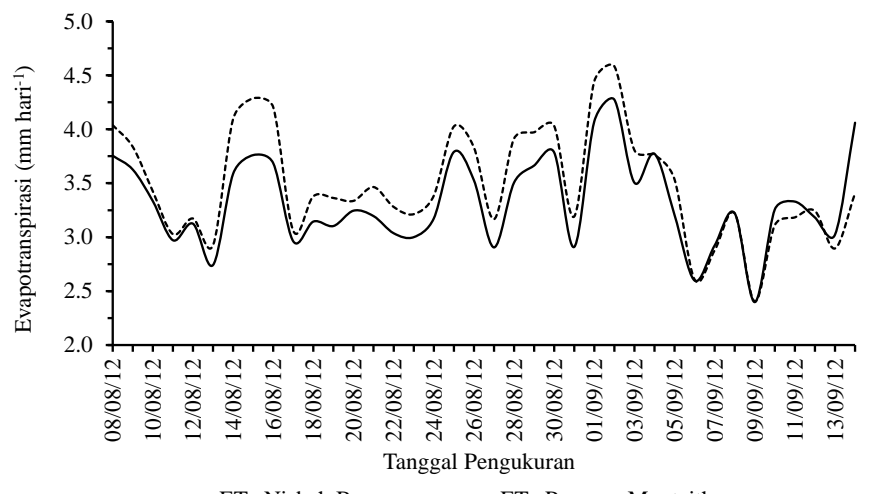

Gambar 4 Perbandingan nilai evapotraspirasi harian menggunakan metode Nisbah Bowen (-) dengan Metode FAO Penman-Monteith (-----)

Hasil analisis korelasi antara rata-rata evapotranspirasi dari metode Nisbah Bowen dan nilai rata-rata evapotranspirasi dari metode FAO Penman-Monteith menunjukkan nilai $\mathrm{P}<0,05$. Hasil ini menunjukkan bahwa rata-rata evapotranspirasi dari metode Nisbah Bowen dan rata-rata evapotranspirasi dari metode FAO Penman-Monteith memiliki hubungan yang signifikan dengan koefisien korelasi sebesar 0,90 .

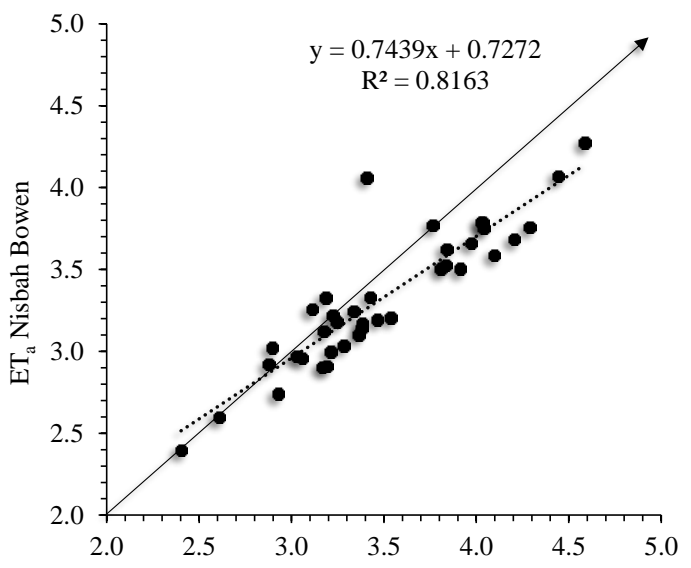

$\mathrm{ET}_{\mathrm{c}}$ FAO Penman Monteith

Gambar 5Diagram pencar evapotraspirasi menggunakan metode Nisbah Bowen (sumbu Y) dan metode FAO Penman-Monteith (sumbu X)

Euser et al. (2013) mendapatkan adanya korelasi limpahan bahang laten yang tinggi antara hasil perhitungan antara metode Bowen Ratio Distributed
Temperature Sensing (BR-DTS) dengan hasil Eddy Covariance dengan koefisien korelasi 0,98. Hollanda et al. (2013) mendapatkan koefisien korelasi 0,99 antara evapotranspirasi hasil perhitungan metode Micro Bowen Ratio dengan hasi pengukuran lisimeter. Dengan demikian metode Nisbah Bowen cukup baik digunakan untuk pendugaan nilai evapotranspirasi aktual.

\subsection{Interaksi Evapotranspirasi dengan Lingkungan dan Tanaman}

Kekeringan yang sering terjadi selama musim tanam II di areal persawahan Indramayu menyebabkan pertumbuhan padi tidak maksimal hingga terjadinya penurunan produktivitas tanaman padi. Padi varietas Ciherang yang memiliki rata-rata produksi $6,0 \mathrm{t} \mathrm{ha}^{-1}$ hanya memiliki produktivitas $1,6 \mathrm{t} \mathrm{ha}^{-1}$, varietas Inpari 10 yang memiliki rata-rata produksi $5,1 \mathrm{t} \mathrm{ha}^{-1}$ hanya memiliki produktivitas $1,7 \mathrm{t} \mathrm{ha}^{-1}$ dan varietas Inpari 13 yang memiliki rata-rata produksi $6,6 \mathrm{t} \mathrm{ha}^{-1}$ hanya memiliki produktivitas $2,0 \mathrm{t} \mathrm{ha}^{-1}$ akibat mengalami kekeringan.

Evapotranspirasi yang terjadi sebesar $3,3 \mathrm{~mm}_{\text {hari }}{ }^{-1}$ lebih rendah dibanding evapotranspirasi yang terjadi di sawah aerobik dan sawah genangan. Hasil penelitian Alberto et al. (2011) di Philipina selama empat musim tahun 2008 dan 2009 dengan rata-rata suhu $27,2{ }^{\circ} \mathrm{C}$ pada musim kemarau dan $27,7^{\circ} \mathrm{C}$ pada musim hujan menunjukkan nilai evapotranspirasi di sawah aerobik sebesar 3,8 $\mathrm{mm}$ hari $^{-1}$ dan sawah genangan sebesar $4,3 \mathrm{~mm}$ hari $^{-1}$. Evapotranspirasi yang rendah merupakan indikasi tanaman kekurangan air dan air tanah berada $\mathrm{d}$ bawah kapasitas lapang. Rendahnya $\mathrm{ET}_{\mathrm{a}}$ pada akhir pertanaman terdeteksi dari penurunan nilai Nisbah Bowen, tetapi tidak terdeteksi dari makin lebarnya selisih antara $\mathrm{ET}_{\mathrm{p}}$ FAO Penman-Monteith dengan $\mathrm{ET}_{\mathrm{a}}$ Nisbah Bowen. Menurut Sulistyono et al. (2011) evapotranspirasi merupakan peubah yang sangat berkaitan dengan produksi tanaman. Pada kondisi defisit air, penurunan produksi berbanding lurus dengan penurunan evapotranspirasi. Penurunan evapotranspirasi atau defisit evapotranspirasi akan menyebabkan penurunan produksi bahan kering tanaman. Semakin tinggi total defisit evapotranspirasi menyebabkan penurunan produksi semakin besar.

\section{Simpulan}

Evapotranspirasi harian di areal persawahan Kabupaten Indramayu pada saat periode kekeringan musim tanam II yang diduga menggunakan metode Nisbah Bowen berkisar antara antara $2,4 \mathrm{~mm}$ sampai $4,3 \mathrm{~mm}$ dengan rata-rata $3,3 \mathrm{~mm}$, sedangkan evapotranspirasi harian yang diduga menggunakan metode FAO Penman-Monteith bervariasi antara $2,4 \mathrm{~mm}$ sampai 4,6 $\mathrm{mm}$ dengan ratarata 3,5 mm. Rata-rata hasil estimasi evapotranspirasi harian dari kedua metode secara statistik tidak berbeda nyata.

\section{Pustaka}

Abdullahi A S, Soom M A M, Ahmad D dan Shariff A R M. 2013. Characterization of rice (Oryza sativa) evapotranspiration using micro paddy lysimeter and class "A" pan in tropical environments. Australian Journal of Crop Science. 7(5):650-658. doi: http://www.cropj.com/abdullahi752013 650658.pdf.

Alberto MCR, Wassmanna R, Hiranob T, Miyatac A, Hatanob R, Kumara A, Padrea A dan Amantea M. 2011. Comparisons of energy balance and evapotranspiration between flooded and aerobic rice fields in the Philippines. Agric. Water Management [Internet]. [diunduh 2014 Maret 8];98(9):1417-1430. Tersedia pada: http://dx.doi.org/10.1016/j.agwat.20 11.04.011.

Angus DE, Watts PJ. 1984. Evapotranspiration how good is the bowen ratio method? Agric. Water Management [Internet]. [diunduh 2012 April 14];8:188-150. Tersedia pada: http://www.sciencedirect.com/science/article/pii/0378377484900507.

Bowen IS. 1926. The ratio of heat losses by conduction and by evaporation from any water surface. Physical Review [Internet]. [diunduh 2012 April 14];27:779-787.

Euser T, Luxemburg W, Everson C, Mengistu M, Clulow A dan Bastiaanssen W. 2013. A new method to measure bowen ratios using high resolution vertical dry and wet bulb temperature profiles. J. Hydrol. Earth Syst. Sci. Discuss. 10: 7161-7196, doi:10.5194/hessd-10-7161-2013.

Grant DR. 1975. Comparisons of evaporation measurement using different methods. Quart. J. Roy. Meteorol. Soc. 101(429):543-550.doi:10.1002/q .49710142911 .

Hollanda S, Heitmana J L, Howarda A, Sauerb T J, Giesec W, Ben-Gald A, Agame N, Koole D dan Havlina J. 2013. Micro-Bowen ratio system for measuring evapotranspiration in a vineyard interrow. J. Agrformet. 117: 93 100.

Jarvis PG, Stewart JB. 1979. Evaporation of water from pantation forest. In: E. D. Ford, D. C. Malcolm dan J. A. Herson (Eds). The ecology of evenage forest plantations [Internet]. Camridge (US): ITE. [diunduh 2012 April 14].

Rossenberg N, Blad B, Verma S. 1983. Microclimate: The Biological Environment. New Jersey (US): J Wiley.

Sulistyono E, Suwarto dan Ramdiayani Y. 2011. Defisit Evapotranspirasi sebagai Indikator Kekurangan Air pada Padi Gogo (Oryza sativa L.). Bul. Agron. [Internet]. [diunduh 2014 Maret 8]; 33(1):6-11. Tersedia pada: http://eprints.undip.ac.id/34353/7/2188_CHAPTER_IV.pdf.

Tanner C. B. dan D. H. Sargeant. 1966. A simple psychrometric apparatus for bowen ratio determination. J. Appl. Meteorol [Internet]. [diunduh 2012 April 14];6:414-418. Tersedia pada: http://dx.doi.org/10.1175/15200450(1967)006<0414:ASPAFB >2.0.CO;2. 
Taolin, R.I.C.O., Impron, Hidayati, R. \& Budianto, B. 2017. Profil Cuaca dan Parameter Nisbah Bowen di Areal Persawahan Kabupaten Indramayu Saat Periode Kering Musim Tanam II. Savana Cendana, 2(01): 15-18.

Wang Y L, Wang X, Zheng Q Y, Li C H dan Guo X J. 2012. A comparative study on hourly real evapotranspiration and potential evapotranspiration during different vegetation growth stages in the zoige wetland. Procedia Environ. Sci. 13:1585-1594.doi:10.1016/j.proenv.2012.01.150. 